\title{
Uptake of dissolved free amino acids (DFAA) by microphytobenthic communities
}

\author{
Frank Linares*, Kristina Sundbäck \\ Department of Marine Ecology, Göteborg University, PO Box 461, 40530 Göteborg, Sweden
}

\begin{abstract}
Although it is established that labile fractions of dissolved organic nitrogen (DON), such as dissolved free amino acids (DFAA), can be utilized by microalgae, few studies have considered their quantitative importance for microphytobenthos (MPB). Mixed MPB communities, from 1 and $20 \mathrm{~m}$ water depth and treated in 2 ways (semi-natural and isolated), and axenic diatom cultures (Cylindrotheca fusiformis) were examined for the uptake of DFAA. Uptake was measured using naturally low concentrations $\left(<1 \mu \mathrm{mol} \mathrm{l}^{-1}\right)$ of a mixture of ${ }^{3} \mathrm{H}$-labeled DFAA $\left({ }^{3} \mathrm{H}-\mathrm{AA}\right)$ under different light conditions and varying levels of dissolved inorganic nitrogen (DIN). Prokaryotic and eukaryotic uptake were differentiated using chloramphenicol. Biomass ( $\mathrm{chl}$ a) and production $\left({ }^{14} \mathrm{C}\right.$ uptake) were measured as well. ${ }^{3} \mathrm{H}$-AA was taken up during the incubations in all experiments: 20 to $40 \%$ in the culture experiments, and 2 to $18 \%$ in the mixed MPB experiments. Of the total adsorption-corrected uptake, prokaryotic uptake accounted for 45 to $85 \%\left(0.3\right.$ to $\left.2.2 \mu \mathrm{mol} \mathrm{N} \mathrm{m} \mathrm{N} \mathrm{h}^{-1}\right)$, while eukaryotic uptake accounted for 15 to $55 \%\left(0.3\right.$ to $\left.0.7 \mu \mathrm{mol} \mathrm{N} \mathrm{m}^{-2} \mathrm{~h}^{-1}\right)$. Short-term (hours) light changes had no effect on ${ }^{3} \mathrm{H}$-AA uptake, and ammonium availability lowered ${ }^{3} \mathrm{H}$-AA uptake only marginally. Shadeadapted MPB communities $(20 \mathrm{~m})$ took up ${ }^{3} \mathrm{H}$-AA more efficiently than light-adapted communities $(1 \mathrm{~m})$. The estimated contribution from DFAA to the microalgal $\mathrm{N}$-demand was 6 to 12 and 55 to $100 \%$ (1 and 20 m sediment, respectively). Our findings suggest that DON, specifically DFAA, may be an important source of N for MPB communities, particularly where DIN and light are limiting. Moreover, tentative estimations suggest that DFAA can provide MPB communities with a considerable portion of their total $\mathrm{N}$-demand (10 to $100 \%$ ).
\end{abstract}

KEY WORDS: Dissolved free amino acids $\cdot$ DFAA $\cdot$ Nitrogen $\cdot$ Sediment $\cdot$ Microphytobenthos $\cdot$ DON

\section{INTRODUCTION}

Dissolved organic nitrogen (DON) is a dynamic component of the nitrogen $(\mathrm{N})$ pool in marine coastal waters (Zehr \& Ward 2002), where its fractions are used not only by heterotrophic bacteria, but also by photoautotrophs (Antia et al. 1991, Mulholland et al. 2002). Because coastal sediments function as important sites for mineralization, pore water DON concentration is often high and hence DON flux often dominates the sediment-water exchange of dissolved N (Lomstein et al. 1998, Tyler et al. 2001, 2003, Sundbäck et al. 2004). In shallow waters where light reaches the sediment surface, benthic primary producers (both macroscopic and microscopic) largely control the $\mathrm{N}$ flux (McGlathery et al. 2004).
Among these, microphytobenthos (MPB) form dynamic microbial mats at the sediment surface, contributing $\geq 50 \%$ of the primary production in shallow estuaries and embayments (Underwood \& Kromkamp 1999, McGlathery et al. 2004). These communities can affect the sediment-water exchange of inorganic nutrients, directly by uptake, and indirectly by oxygen production (Henriksen et al. 1980, Sundbäck et al. 2000, for further references see McGlathery et al. 2004). MPB can also control bacterial processes such as nitrification and denitrification by producing oxygen and competing for $\mathrm{N}$ with bacteria (Risgaard-Petersen 2003). Recent studies suggest that MPB, and other benthic primary producers, are also important in controlling the turnover of DON in shallow areas (Anderson et al. 2003, Tyler et al. 2003). 
Little is known about the quantitative importance of DON fractions for the growth of natural MPB communities. One obvious reason is that controlled uptake experiments are difficult to do in natural sediments, mainly because of the indigenous pool of inorganic and organic nutrients in the sediment pore water (cf. Nilsson \& Sundbäck 1991). In addition, MPB has been generally thought to have an inexhaustible pool of available nutrients in the interstitial waters (Underwood \& Kromkamp 1999). Dissolved free amino acids (DFAA) constitute a labile component of DON that is readily available both as a $\mathrm{N}$ and carbon (C) source for growth (Antia et al. 1991, Mulholland et al. 2002). Culture experiments have shown that growth of benthic diatoms can be stimulated by the addition of DON, such as DFAA (Admiraal \& Peletier 1979), and that benthic diatoms take up DFAA occurring at low, natural concentrations (Admiraal et al. 1984, 1987). While the quantitative role of DFAA has been studied to some extent for phytoplankton (Mulholland et al. 2002, Veuger et al. 2004) and diatoms freshly isolated from low-light benthic communities (Rivkin \& Putt 1987), only a few studies have tried to estimate the role of DFAA in natural MPB communities in sediments (Nilsson Sundbäck 1996, Linares in press).

In marine waters, DFAA concentrations are usually below $1 \mu \mathrm{M}$ (Mulholland et al. 2003). In shallow-water sediments, DFAA can constitute between 10 and $30 \%$ of the DON pool (Lomstein et al. 1998, Guldberg et al. 2002). The mixture of frequent light-limiting conditions, and the high concentrations of dissolved organic compounds found in sediments should imply that the capacity to use organic substrates is a selective advantage for algae in sediments. This could particularly apply to conditions of low availability of dissolved inorganic nitrogen (DIN), such as shallow sandy sediment areas, where DIN often appears to be limiting (Nilsson et al. 1991, Flothman \& Werner 1992). It has been hypothesized that MPB can sustain a high production rate under low DIN conditions, because nutrients (particularly DON) are rapidly recycled and reused by the microbial mats at the sediment surface (Kristensen 1993, Lomstein et al. 1998, Sundbäck et al. 2000), thereby efficiently retaining $N$ within the sediment system. A recent study showed that DFAA indeed stimulates MPB biomass and production in sandy sediments (Linares in press). The aim of our study was to estimate uptake of DFAA by mixed MPB communities. Our hypothesis was that MPB could make use of a large fraction of DFAA, even when available at naturally low concentrations, particularly when DIN was limiting. A second hypothesis was that shade-adapted MPB communities could take up DFAA more efficiently than light-adapted communities. The approach was to measure uptake of a ${ }^{3} \mathrm{H}$-labeled DFAA $\left({ }^{3} \mathrm{H}\right.$-AA) mixture under different light conditions and in the presence of DIN.

\section{MATERIALS AND METHODS}

General approach. Measuring nutrient uptake in sediments under in situ conditions is difficult. For instance, DON can be adsorbed onto sediment particles (Christensen \& Blackburn 1980, Aufdekampe et al. 2001), to high molecular weight dissolved organic matter (Schuster et al. 1998), to the surfaces of microorganisms (Carman \& Guckert 1994), or it can be used by microbiota such as bacteria. In addition, nutrient availability is difficult to control because of the indigenous nutrient pool of the pore water. In order to minimize these sources of error, we used 3 types of microalgal material in our experiments: (1) an axenic unialgal diatom culture, (2) MPB communities isolated from natural sediment onto chemically cleaned sand (isolated communities, IC), and (3) MPB communities in natural, but gently sieved, sediment (semi-natural communities, SNC). A series of experiments was carried out (Table 1) using a ${ }^{3} \mathrm{H}$-AA mixture (Amersham TRK-440, Table 2). Two treatments were made, one with the ${ }^{3} \mathrm{H}$-AA mixture plus an addition of ammonium $\left(\mathrm{NH}_{4}\right)\left(+\mathrm{NH}_{4}\right.$ treatment), and one with the ${ }^{3} \mathrm{H}-\mathrm{AA}$ mixture alone $\left(-\mathrm{NH}_{4}\right.$ treatment). Killed material was used as an adsorption control, and a protein synthesis inhibitor (chloramphenicol, CAP) was used to discriminate between prokaryotic and eukaryotic uptake. See Table 1 for experiment specifications.

Setup of culture experiments. An axenic culture of the pennate diatom Cylindrotheca fusiformis Reimann and Lewin Culture Collection of Algae and Protozoa (CCAP) was used in 4 experiments to test washing, adsorption, and tracer additions (Table 1). Since the culture was axenic, we assume ${ }^{3} \mathrm{H}$-AA was taken up only by live cells or adsorbed onto algal cells and the filter used. To create N-limiting conditions, a known amount of cells was transferred to a $50 \mathrm{ml}$ Nunc flask with artificial seawater (ASW) with no added nutrients, and were kept for $4 \mathrm{~d}$ prior to the uptake experiments. In the first 3 experiments, only live cells were used to test washing and addition of ${ }^{3} \mathrm{H}-\mathrm{AA}$. In Expt 4 , cells killed by heat $\left(5 \mathrm{~min}\right.$ at $120^{\circ} \mathrm{C}$ ) were also incubated to assess the proportion of label adsorbed to surfaces (Table 1).

Setup of mixed community experiments. Uptake of ${ }^{3} \mathrm{H}-\mathrm{AA}$ in mixed MPB communities was measured in 4 experiments, with an additional washing test (Table 1). Sandy sediment (top 0.5 to $1 \mathrm{~cm}$ ) was collected from 2 sites: from $\leq 1 \mathrm{~m}$ depth in a shallow bay in the NE Kattegat $\left(57^{\circ} 40^{\prime} \mathrm{N}, 11^{\circ} 55^{\prime} \mathrm{E}\right)$, and from 1 and $20 \mathrm{~m}$ depth in the Gullmar Fjord (58 $\left.22^{\prime} \mathrm{N}, 11^{\circ} 37^{\prime} \mathrm{E}\right)$, on the Swedish west coast. The sediment was mixed in a plastic tray and spread evenly. Filtered seawater (Whatman GF/F) from the sampling site was added, and the sediment was left to settle overnight at $10^{\circ} \mathrm{C}$. 
Table 1. Experimental design and specifications for all of the experiments in the study. Type/Depth: IC, isolated microphytobenthic community; SNC, semi-natural microphytobenthic community. Treatments: L, light; D, dark (numbers in parentheses are light irradiance, in $\mu \mathrm{mol}$ photons $\mathrm{m}^{-2} \mathrm{~s}^{-1}$ ); CAP, chloramphenicol prokaryotic inhibitor. Variables measured: AA, amino acid uptake; Chl, chlorophyll $a_{i} \mathrm{CC}$, cell counts; Sp, species composition; PP, primary productivity $\left({ }^{14} \mathrm{C}\right)$

\begin{tabular}{|c|c|c|c|c|c|c|c|}
\hline Expt & $\begin{array}{c}\text { Type/ } \\
\text { Depth (m) }\end{array}$ & $\begin{array}{c}\text { Temp. }\left({ }^{\circ} \mathrm{C}\right) / \\
\text { Salinity }\end{array}$ & $\begin{array}{c}{ }^{3} \mathrm{H}-\mathrm{AA} \\
\left(\mathrm{nmol} \mathrm{l}^{-1}\right)\end{array}$ & Treatment & $\begin{array}{c}\text { Cell } \\
\text { condition }\end{array}$ & $\begin{array}{l}\text { Variables } \\
\text { measured }\end{array}$ & Comment \\
\hline 1 & $\begin{array}{c}\text { Culture/Sed. } \\
\text { (method test)/ } \\
0.5\end{array}$ & $10 / 26$ & 128 & L (250) & Live cells & $\mathrm{AA}, \mathrm{CC}$ & $\begin{array}{c}\text { Washing } \\
\text { experiment }\end{array}$ \\
\hline 2 & $\begin{array}{c}\text { Culture } \\
\text { (method test)/ } \\
0.5\end{array}$ & $10 / 26$ & $32-640$ & L (250) & Live cells & $\mathrm{AA}, \mathrm{CC}$ & $\begin{array}{c}\text { Different } \\
\text { DFAA } \\
\text { concentrations }\end{array}$ \\
\hline 3 & $\begin{array}{c}\text { Culture } \\
\text { (method test)/ } \\
0.5\end{array}$ & $10 / 26$ & 32 and 128 & L (250) & Live cells & $\mathrm{AA}, \mathrm{CC}$ & $\begin{array}{c}\text { Different } \\
\text { cell } \\
\text { concentrations }\end{array}$ \\
\hline 4 & $\begin{array}{c}\text { Culture } \\
\text { (method test)/ } \\
0.5\end{array}$ & $10 / 26$ & 128 & $\mathrm{~L}+\mathrm{D}(100,250)$ & $\begin{array}{l}\text { Live and } \\
\text { killed } \\
\text { cells }\end{array}$ & $\mathrm{AA}, \mathrm{CC}$ & $\begin{array}{r}2 \text { light } \\
\text { levels }\end{array}$ \\
\hline 5 & $\mathrm{IC} / 1$ & $10 / 26$ & 128 & $\begin{array}{c}\mathrm{L}+\mathrm{D}(250) \\
7.5 \mu \mathrm{mol} \mathrm{l}^{-1} \\
\mathrm{NH}_{4}\end{array}$ & $\begin{array}{l}\text { Live and } \\
\text { killed } \\
\text { cells }\end{array}$ & $\mathrm{AA}, \mathrm{Chl}$ & $\begin{array}{c}\text { Effect of } \\
\mathrm{NH}_{4} \\
\text { availability }\end{array}$ \\
\hline 6 & $\mathrm{IC} / 1$ & $10 / 26$ & 128 & $\begin{array}{c}\mathrm{L}+\mathrm{D}(250) \\
20 / 100 \mu \mathrm{mol} \mathrm{l} \mathrm{l}^{-1} \\
\text { CAP }\end{array}$ & $\begin{array}{l}\text { Live and } \\
\text { inhibited } \\
\text { cells }\end{array}$ & $\mathrm{AA}, \mathrm{Chl}$ & $\begin{array}{c}\text { Prokaryotic and } \\
\text { eukaryotic } \\
\text { uptake }\end{array}$ \\
\hline 7 & $\begin{array}{c}\text { IC, SNC/ } \\
0.5\end{array}$ & $10 / 26$ & 128 & $\begin{array}{c}\mathrm{L}(250) \\
7.5 \mu \mathrm{mol} \mathrm{NH} \mathrm{NH}_{4} \\
20 \mu \mathrm{mol} \mathrm{l}^{-1} \mathrm{CAP}\end{array}$ & $\begin{array}{c}\text { Live, killed } \\
\text { and inhibited } \\
\text { cells }\end{array}$ & $\begin{array}{c}\text { AA, Chl, } \\
\text { PP }\end{array}$ & ${ }^{14} \mathrm{C}$ productivity \\
\hline 8 & $\begin{array}{c}\text { IC, SNC/ } \\
1,20\end{array}$ & $10 / 26$ & 500 & $\begin{array}{c}\mathrm{L}(250,10) \\
7.5 \mu \mathrm{mol} \mathrm{NH} \\
20 \mu \mathrm{mol} \mathrm{l}^{-1} \mathrm{CAP}\end{array}$ & $\begin{array}{l}\text { Live, killed } \\
\text { and inhibited } \\
\text { cells }\end{array}$ & $\begin{array}{c}\mathrm{AA}, \mathrm{Chl}, \\
\text { PP }\end{array}$ & $\begin{array}{c}\text { Light-adapted } \\
\text { sediment }(1 \mathrm{~m}), \\
\text { Shade-adapted } \\
\text { sediment }(20 \mathrm{~m})\end{array}$ \\
\hline
\end{tabular}

The sediment was divided into 2 portions. To remove natural pore-water nutrients, the MPB community was isolated from the sediment (IC). The sediment was stirred with filtered seawater to separate the motile microalgae (epipelic fraction) from the sediment. The remaining sediment was ultra-sonicated for $10 \mathrm{~min}$, to detach algae attached to particles (epipsammic fraction). This treatment did not destroy cells (cf. Voltolina 1991). Both fractions were put in a tray with a $2 \mathrm{~cm}$ layer of chemically cleaned sand (MERCK Eurolab). The SNC was created by gently sieving the sediment through a $500 \mu \mathrm{m}$ mesh to remove macrofauna. Both communities were left to acclimatize for a period of $4 \mathrm{~d}$ to $1 \mathrm{wk}$ depending on the experiment, on a $14: 10 \mathrm{~h}$ light: dark cycle $\left(250 \mu \mathrm{mol}\right.$ photons $\mathrm{m}^{-2} \mathrm{~s}^{-1}$ for the $1 \mathrm{~m}$ sediment, and $10 \mu \mathrm{mol}$ photons $\mathrm{m}^{-2} \mathrm{~s}^{-1}$ for the $20 \mathrm{~m}$ sediment).

Incubation for measuring DFAA uptake. All 3 types of algal material were incubated in $10 \mathrm{ml}$ sterile Polystyrene test tubes in $6 \mathrm{ml}$ of ASW (Table 1). In the culture experiments, 15000 to 60000 cells ml ${ }^{-1}$ were inoculated. SNC and IC samples were taken with a $2 \mathrm{ml}$ cut-off syringe ( $5 \mathrm{~mm}$ deep, area $0.567 \mathrm{~cm}^{-2}$ ) and were transferred to tubes with ASW prior to incubation, thereby creating N-limiting conditions. All incubations (except Expts 1 to 3 and 6) included an adsorption control in triplicate with killed cells. An amino acid mixture consisting of $15{ }^{3} \mathrm{H}$-AA (Amersham Biosciences, TRK 440, Table 2) was added to each tube $\left(-\mathrm{NH}_{4}\right.$ treat-

Table 2. Proportions of the 15 different ${ }^{3} \mathrm{H}$-labeled amino acids in the mixture used in the incubations (Amersham, TRK 440)

\begin{tabular}{|lc|}
\hline Amino acid & Proportion $(\%)$ \\
\hline Alanine & 7.0 \\
Arginine & 3.7 \\
Aspartic acid & 15.5 \\
Glutamic acid & 6.2 \\
Glycine & 13.8 \\
Histidine & 0.9 \\
Isoleucine & 2.0 \\
Leucine & 6.9 \\
Lysine & 2.0 \\
Phenylalanine & 8.9 \\
Proline & 6.0 \\
Serine & 3.3 \\
Threonine & 13.4 \\
Tyrosine & 4.1 \\
Valine & 6.3 \\
\hline
\end{tabular}


ment). The composition of the mixture is close to that found in the pool of pore-water DON (Lomstein et al. 1998, Guldberg et al. 2002). To test the effect of DIN availability, $\mathrm{NH}_{4}$ was added as $\mathrm{NH}_{4} \mathrm{Cl}$ in Expts 5,7 and $8\left(+\mathrm{NH}_{4}\right.$ treatment), to a final concentration of $7.5 \mu \mathrm{mol} \mathrm{l} \mathrm{l}^{-1}$, approximately the highest concentration found in shallow waters in the study area (Sundbäck et al. 2000). Ambient $\mathrm{NH}_{4}$ concentration in the overlying water was $1.1 \mu \mathrm{mol} \mathrm{l}^{-1}$. $\mathrm{NH}_{4} \mathrm{Cl}$ was added ca. $30 \mathrm{~min}$ before the addition of ${ }^{3} \mathrm{H}-\mathrm{AA}$.

The amount of label added was determined by incubating Cylindrotheca fusiformis cells (15000 cells ml-1) in a range of ${ }^{3} \mathrm{H}-\mathrm{AA}$ concentrations (32 to $640 \mathrm{nM}$ ),
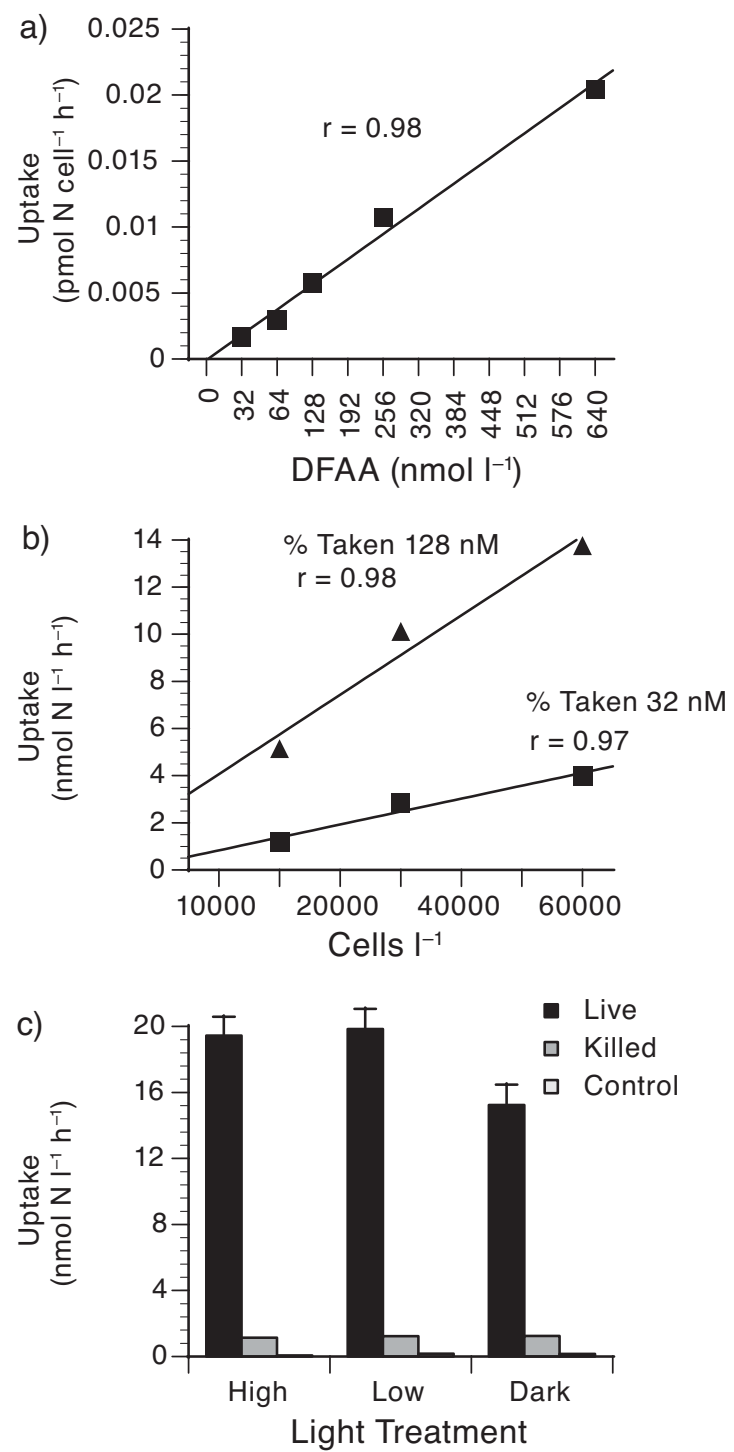

Fig. 1. Cylindrotheca fusiformis. Dissolved free amino acid (DFAA) uptake (+SE), Expts 2 to 4 (Table 1). (a) Uptake per cell at different DFAA concentrations; (b) DFAA taken up at different cell concentrations and $2{ }^{3} \mathrm{H}$-labeled $\left({ }^{3} \mathrm{H}-\mathrm{AA}\right)$ concentrations (32 and $128 \mathrm{nM}$ ); (c) uptake of DFAA under high and low light conditions and in the dark (Table 1) and then incubating a range of cells (15000 to 60000 cells $\mathrm{ml}^{-1}$ ) at 2 specific ${ }^{3} \mathrm{H}$-AA concentrations (32 and $128 \mathrm{nM}$ ). A final addition of $128 \mathrm{nM}$ of ${ }^{3} \mathrm{H}-\mathrm{AA}$ was used in all experiments, except for Expt 9 (500 nM). By using these low concentrations we hoped not to enrich natural, ambient pore-water concentrations, which range from 0.3 to $30 \mu \mathrm{mol}$ of DFAA (Admiraal et al. 1987, Antia et al. 1991).

To differentiate between prokaryotic and eukaryotic ${ }^{3} \mathrm{H}-\mathrm{AA}$ uptake, a bacteriostatic inhibitor chloramphenicol (CAP) was used in Expts 6 to 8 (Table 1). CAP was added 30 min before incubation. Tubes were incubated for 3 to $4 \mathrm{~h}$ at $10^{\circ} \mathrm{C}$. Positional irradiance effects from the incubation lamps were avoided by randomly moving each tube every $30 \mathrm{~min}$. Irradiance ranged from 10 to $250 \mu \mathrm{mol}$ photons $\mathrm{m}^{-2} \mathrm{~s}^{-1}$ (Table 1). In Expt 4, 2 light levels were used ( 100 and 250 photons $\mathrm{m}^{-2} \mathrm{~s}^{-1}$ ). In Expts 4 to 6 dark incubations were also made. All treatments were run in triplicate. Samples were collected by vacuum filtration onto Polycarbonate filters (0.2 $\mu \mathrm{m}$, Osmonics), and were washed with $20 \mathrm{ml}$ of ASW. Uptake was measured in a scintillation counter, after addition of Hionic Fluor scintillation cocktail (Packard). ${ }^{3} \mathrm{H}-\mathrm{AA}$ uptake was recalculated to uptake per $\mathrm{m}^{2}$, using the sampled sediment surface. Uptake normalized to chlorophyll a $\left({ }^{3} \mathrm{H}-\mathrm{AA}^{\mathrm{chl} a}\right)$ was used to compare the uptake efficiency between communities with different algal biomass.

Primary production. Primary production (PP) was measured as ${ }^{14} \mathrm{C}$-uptake during Expts 7 and 8. Eighty $\mu \mathrm{l}$ of $\mathrm{H}^{14} \mathrm{CO}_{3}$ (activity $20.54 \mu \mathrm{Ci} \mathrm{ml}{ }^{-1},{ }^{14} \mathrm{C}$ Agency Denmark) were added to each tube. Samples were incubated for $4 \mathrm{~h}$ under the same conditions as the corresponding ${ }^{3} \mathrm{H}$-AA tubes. A mixture of unlabeled DFAA was added to all tubes to mimic the conditions in the ${ }^{3} \mathrm{H}-\mathrm{AA}$ tubes, and $\mathrm{NH}_{4} \mathrm{Cl}$ was added to a final concentration of $7.5 \mu \mathrm{mol} \mathrm{l}^{-1}$. The ${ }^{14} \mathrm{C}$-samples were processed as described by Sundbäck et al. (1990). Total carbon dioxide $\left(\mathrm{CO}_{2}\right)$ concentration was calculated using the equations described by Aertebjerg Nielsen \& Bresta (1984).

Chlorophyll a. Chl a was used as a measure of MPB biomass. Three sediment samples (5 mm deep) were taken from the IC and SNC sediments before the start of each experiment using a $2 \mathrm{ml}$ cut-off syringe, and were frozen at $-80^{\circ} \mathrm{C}$. Pigment content was extracted by adding $3 \mathrm{ml}$ of $100 \%$ acetone to each sample. The tubes were ultra-sonicated for $10 \mathrm{~min}$ (while cooling with ice). Samples were left for $24 \mathrm{~h}$ at $7^{\circ} \mathrm{C}$ in darkness, after which they were centrifuged for $10 \mathrm{~min}$ at $2000 \mathrm{rpm}(750 \times \mathrm{g})$. Samples were analyzed with a spectrophotometer (Shimadzu UV-2401 PC), correcting for phaeopigment degradation according to Lorenzen (1967).

Analysis of dissolved nitrogen. A TRAACS autoanalyzer (Bran \& Lubbe) was used for the analysis of $\mathrm{NH}_{4}$, nitrate plus nitrite and total dissolved nitrogen (TDN) from pore water and overlying water in Expt 8. 
Table 3. Summary of results from Expts 7 and 8. All values have been corrected for DFAA adsorption. Percent of the added label taken up, measured uptake rate of ${ }^{3} \mathrm{H}$-DFAA including amount and proportion of prokaryotic (Prok.) and eukaryotic (Euk.) uptake, primary production (PP) and chlorophyll-normalized production (PP/Chl), estimated DFAA uptake and percent of estimated $\mathrm{N}$-demand (SNC in Expt 8) assuming 10 and $20 \%$ of DON pool is DFAA. IC: isolated community: SNC: semi-natural community

\begin{tabular}{|c|c|c|c|c|c|c|c|c|c|c|c|c|c|}
\hline \multirow[t]{3}{*}{ Expt } & \multirow[t]{3}{*}{ Type } & \multirow[t]{3}{*}{$\begin{array}{l}\text { Depth } \\
\text { (m) }\end{array}$} & \multirow[t]{3}{*}{$\begin{array}{l}\text { Treat- } \\
\text { ment }\end{array}$} & \multirow{3}{*}{$\begin{array}{c}\text { Uptake } \\
\text { of added } \\
\text { label } \\
(\%)\end{array}$} & \multicolumn{3}{|c|}{ 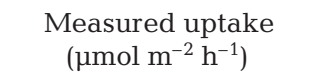 } & \multirow{3}{*}{$\begin{array}{c}\mathrm{PP} \\
(\mathrm{mg} \mathrm{C} \\
\left.\mathrm{m}^{-2} \mathrm{~h}^{-1}\right)\end{array}$} & \multirow{3}{*}{$\begin{array}{c}\mathrm{PP} / \mathrm{Chl} \\
(\mathrm{mg} \mathrm{C} \\
\left.\mathrm{chl}^{-1} \mathrm{~h}^{-1}\right)\end{array}$} & \multirow{2}{*}{\multicolumn{2}{|c|}{$\begin{array}{c}\text { Actual N- } \\
\text { uptake } \\
\left(\mu \mathrm{mol} \mathrm{m} \mathrm{m}^{-2} \mathrm{~h}^{-1}\right)\end{array}$}} & \multirow{2}{*}{\multicolumn{2}{|c|}{$\begin{array}{c}\% \\
\text { of } \mathrm{N}- \\
\text { demand }^{3}\end{array}$}} \\
\hline & & & & & Total & Prok. & Euk. & & & & & & \\
\hline & & & & & & & & & & $10 \%$ & $20 \%$ & $10 \%$ & $20 \%$ \\
\hline \multirow[t]{4}{*}{7} & IC & 0.5 & $-\mathrm{NH}_{4}$ & 7.6 & 1.1 & $0.7(65)$ & 0.4 (35) & 24.8 & 1.4 & & & & \\
\hline & & & $+\mathrm{NH}_{4}$ & 8.9 & 1.0 & $0.7(65)$ & 0.3 (35) & 24.0 & 1.4 & & & & \\
\hline & SNC & 0.5 & $-\mathrm{NH}_{4}$ & 8.9 & 1.2 & $0.6(46)$ & $0.6(54)$ & 64.0 & 0.7 & & & & \\
\hline & & & $+\mathrm{NH}_{4}$ & 9.1 & 1.2 & $0.7(56)$ & $0.5(44)$ & 61.4 & 0.7 & & & & \\
\hline \multirow[t]{8}{*}{8} & IC & 1 & $-\mathrm{NH}_{4}$ & 3.7 & 2.0 & $1.6(80)$ & $0.4(20)$ & 8.3 & 0.7 & & & & \\
\hline & & & $+\mathrm{NH}_{4}$ & 6.2 & 1.7 & $1.5(85)$ & 0.3 (15) & 4.8 & 0.4 & & & & \\
\hline & SNC & 1 & $-\mathrm{NH}_{4}$ & 3.2 & 1.7 & $1.2(73)$ & $0.5(27)$ & 6.1 & 0.1 & 5.6 & 11.2 & 6.0 & 12.1 \\
\hline & & & $+\mathrm{NH}_{4}$ & 2.9 & 1.6 & $1.2(75)$ & $0.4(25)$ & 5.2 & 0.1 & 4.9 & 9.8 & 6.0 & 12.0 \\
\hline & $\mathrm{IC}$ & 20 & $-\mathrm{NH}_{4}$ & 4.9 & 2.6 & $2.2(84)$ & 0.4 (16) & 0.6 & 0.4 & & & & \\
\hline & & & $+\mathrm{NH}_{4}$ & 3.4 & 1.8 & $1.5(84)$ & $0.3(16)$ & 1.3 & 0.9 & & & & \\
\hline & SNC & 20 & $-\mathrm{NH}_{4}$ & 2.6 & 1.5 & $1.1(77)$ & 0.4 (23) & 0.4 & 0.02 & 3.4 & 8.0 & 56.8 & 113.6 \\
\hline & & & $+\mathrm{NH}_{4}$ & 1.1 & 0.6 & $0.3(52)$ & $0.3(48)$ & 0.3 & 0.01 & 3.5 & 7.0 & 53.6 & 107.3 \\
\hline
\end{tabular}

Samples were collected in triplicate by centrifuging a known amount of sediment, and freezing the supernatant at $-80^{\circ} \mathrm{C}$. TDN was analyzed using the persulfate oxidation method (Valderrama 1981, Bronk et al. 2000). DON was calculated by subtracting DIN from TDN.

Species composition. Sediment samples collected using a $2 \mathrm{ml}$ cut-off syringe, and preserved with glutaraldehyde (final concentration of $2.5 \%$ ), were inspected semi-quantitatively using epifluorescence microscopy and phase contrast (Zeiss Axiophot Plan II) at 40× magnification. Both the epipelic and epipsammic fractions were separated and identified to major microalgal groups.

Statistical analysis. The results were analyzed by 1-way ANOVA with treatment $\left(-\mathrm{NH}_{4}\right.$ and $+\mathrm{NH}_{4}$, and light level, respectively) and community type (prokaryotic and eukaryotic) as the fixed factors in their respective cases. Differences between treatments were considered significant when $\mathrm{p}<0.05$.

\section{RESULTS}

We found uptake of ${ }^{3} \mathrm{H}$-AA (Figs. 1 to 3 , Table 3) during the incubations in all experiments: 20 to $40 \%$ in the culture experiments, and 2 to $18 \%$ in the mixed MPB experiments. Of the total uptake, 4 to $19 \%$ was due to adsorption to surfaces (cells, sediment particles), i.e. non-biological uptake (Figs. 1c \& 2a). Initial method tests using different concentrations of Cylindrotheca fusiformis cells showed that uptake increased linearly with increasing ${ }^{3} \mathrm{H}-\mathrm{AA}$ additions, and increasing cell numbers (Fig. 1a,b), suggesting that uptake was mainly biological. Adsorptioncorrected uptake for the culture experiments varied between 1.2 and $14 \mathrm{nmol} \mathrm{l}^{-1}$, or 2 and $15 \mathrm{nmol}^{3} \mathrm{H}-\mathrm{AA}$ cell ${ }^{-1} \mathrm{~h}^{-1}$. Total adsorption-corrected ${ }^{3} \mathrm{H}$-AA uptake rates per $\mathrm{m}^{2}$ (eukaryotic + prokaryotic) were within the same range $\left(0.6\right.$ and $\left.2.6 \mu \mathrm{mol} \mathrm{m} \mathrm{m}^{-2} \mathrm{~h}^{-1}\right)$ for both IC and SNC (Fig. 3, Table 3). However, on one occasion (Gullmar Fjord, $20 \mathrm{~m}$ ) the total uptake by IC was significantly higher $\left(2.6 \mu \mathrm{mol} \mathrm{m}{ }^{-2} \mathrm{~h}^{-1}\right)$ when compared with the SNC at the same depth $\left(1.5 \mu \mathrm{mol} \mathrm{m} \mathrm{m}^{-2} \mathrm{~h}^{-1}\right.$, Fig. 3).

The addition of CAP at 2 concentrations (20 and $100 \mathrm{umol} \mathrm{l}^{-1}$ ) resulted in a similar percentage of inhibition, and $20 \mu \mathrm{mol} \mathrm{l}^{-1}$ was used in all subsequent experiments (Fig. 2b). Prokaryotic uptake was proportionally higher than eukaryotic uptake (ANOVA, p < 0.05) in most cases (Figs. $2 b$ \& 3 ). Prokaryotic uptake ranged from 45 to $85 \%$ of the total adsorption-corrected uptake, or 0.3 to $2.2 \mu \mathrm{mol} \mathrm{N} \mathrm{m}^{-2} \mathrm{~h}^{-1}$ (Table 3). Eukaryotic uptake ranged from 15 to $55 \%$, or 0.3 to $0.7 \mu \mathrm{mol}$ $\mathrm{N} \mathrm{m}^{-2} \mathrm{~h}^{-1}$ (Table 3, Fig. 3).

Chl a measurements showed that MPB biomass varied between the different communities (Fig. 4, text value). Therefore, to compare uptake 'efficiency' between communities, eukaryotic uptake was normalized for chl a $\left({ }^{3} \mathrm{H}-\mathrm{AA}^{\mathrm{chl}}{ }^{\mathrm{a}}\right)$. Since diatoms dominated, cyanobacteria being rare, we assumed that eukaryotic uptake represented the main part of algal uptake. ${ }^{3} \mathrm{H}-\mathrm{AA}^{\text {chl a }}$ accentuated the difference in eukaryotic uptake between the IC and SNC, as well as between sampling depths (Fig. 4). Algae in the IC took up significantly more ${ }^{3} \mathrm{H}-\mathrm{AA}$ per unit chl a than those in the SNC (ANOVA, p < 0.05). In the $20 \mathrm{~m}$ sediment, 
${ }^{3} \mathrm{H}-\mathrm{AA}{ }^{\text {chl a }}$ for the IC was an order of magnitude higher than in the $1 \mathrm{~m}$ sediment (see below). A similar magnitude of difference also existed between IC and SNC for the 20 m sediment.

\section{Short-term light effects}

Irradiance during the incubation had an effect only in the culture experiments. Uptake in the dark by Cylindrotheca fusiformis was slightly, but significantly (ANOVA, $\mathrm{p}<0.05$ ), lower than in the light (Fig. 1c). No significant difference in ${ }^{3} \mathrm{H}$-AA uptake was seen when cells were incubated at 2 different light levels (100 and $250 \mu \mathrm{mol}$ photons $\mathrm{m}^{-2} \mathrm{~s}^{-1}$ ) (Fig. 1c). Incubation of IC sediment in light and dark resulted in no significant light effects (Fig. 2a). Based on this, we decided not to measure dark uptake in the subsequent community experiments.

\section{DFAA uptake in shade- and light-adapted sediment communities}

Eukaryotic uptake $\left({ }^{3} \mathrm{H}-\mathrm{AA}^{\text {chl a }}\right)$ in the IC was an order of magnitude higher for shade-adapted sediment (20 m), ranging from 200 to $300 \mathrm{nmol} \mathrm{N} \mathrm{mg} \mathrm{chl} a^{-1} \mathrm{~h}^{-1}$, than the $1 \mathrm{~m} \mathrm{IC} \mathrm{(ca.} 25 \mathrm{nmol} \mathrm{N} \mathrm{mg} \mathrm{chl} a^{-1} \mathrm{~h}^{-1}$ ) (Fig. 4). For the SNC, the difference was smaller, but still significant (ANOVA, p < 0.05), ca. 8 vs. $14 \mathrm{nmol} \mathrm{mg} \mathrm{chl} a^{-1} \mathrm{~h}^{-1}$ (Fig. 4). The chl a-normalized production ( $\mathrm{P}^{\mathrm{chl} a}$ ) was higher for the IC than SNC, following the pattern of ${ }^{3} \mathrm{H}-\mathrm{AA}^{\text {chl a }}$ (Fig. 5). $\mathrm{P}^{\mathrm{chl} \text { a }}$ was an order of magnitude lower for the SNC (Fig. 5).

\section{Effect of DIN availability}

The effect of DIN on ${ }^{3} \mathrm{H}$-AA uptake was only measured in the community experiments. No effects were found in Expts 5 and 7 (Figs. 2a, 3a \& 4a). In Expt 8, the presence of $\mathrm{NH}_{4}$ significantly lowered eukaryotic ${ }^{3} \mathrm{H}$-AA uptake in the IC but not in the SNC (Fig. 3b,c). This effect was most obvious for the ${ }^{3} \mathrm{H}-\mathrm{AA}{ }^{\text {chl a }}$ uptake rates, where $\mathrm{NH}_{4}$ addition decreased tracer uptake by as much as $30 \%$ (Fig. 4b,c). In Expt 8, $\mathrm{NH}_{4}$ addition also affected $\mathrm{P}^{\mathrm{chl}}{ }^{\mathrm{a}}$, but only in the IC and with different direction of effects (Fig. 5).

\section{Estimated DFAA uptake and N-demand of MPB}

Our DFAA uptake rates are probably underestimations of the actual uptake, particularly for the sediment communities. Measuring true DFAA uptake rates with tracer techniques requires that the indigenous DFAA pool in the pore water be taken into account (Mulholland et al. 2002). In Expt 8 we roughly estimated the actual uptake of DFAA by microalgae, as well as its contribution to the algal $\mathrm{N}$-demand in the SNC. Uptake was calculated according to the formula: \% label taken up by eukaryotes $\times$ DFAA concentration in the pore water (Mulholland et al. 2002). We assumed the DFAA pool to be either 10 or $20 \%$ of the measured DON pool in the pore water (Guldberg et al. 2002, their Table 1). Mean DON concentration was $63 \mu \mathrm{M}$ in the pore water (1 and $20 \mathrm{~m}$ sediments), giving an estimated DFAA concentration of $12.6 \mu \mathrm{M}$ $(20 \%)$ or $6.3 \mu \mathrm{M}(10 \%)$. Uptake of ${ }^{3} \mathrm{H}-\mathrm{AA}$ was 3.5 to $5.6 \mu \mathrm{mol} \mathrm{m} \mathrm{m}^{-2} \mathrm{~h}^{-1}$ (10\% DFAA in the DON pool) and 7 to $11.3 \mu \mathrm{mol} \mathrm{m} \mathrm{m}^{-2} \mathrm{~h}^{-1}$ (20\% DFAA in the DON pool) (Table 3 ). The algal $\mathrm{N}$-demand was calculated from primary production, assuming a $\mathrm{C} / \mathrm{N}$ ratio of 6.6 (Redfield). Assuming that $10 \%$ of the available DON pool is DFAA, the contribution to the algal N-demand that comes from DFAA was $6 \%$ for the $1 \mathrm{~m}$ sediment, and $55 \%$ for the $20 \mathrm{~m}$ sediment (Table 3). If $20 \%$ of the available DON pool is assumed to be DFAA, the contribution is $12 \%$ for the $1 \mathrm{~m}$ sediment, and $110 \%$ for the $20 \mathrm{~m}$ sediment (Table 3).
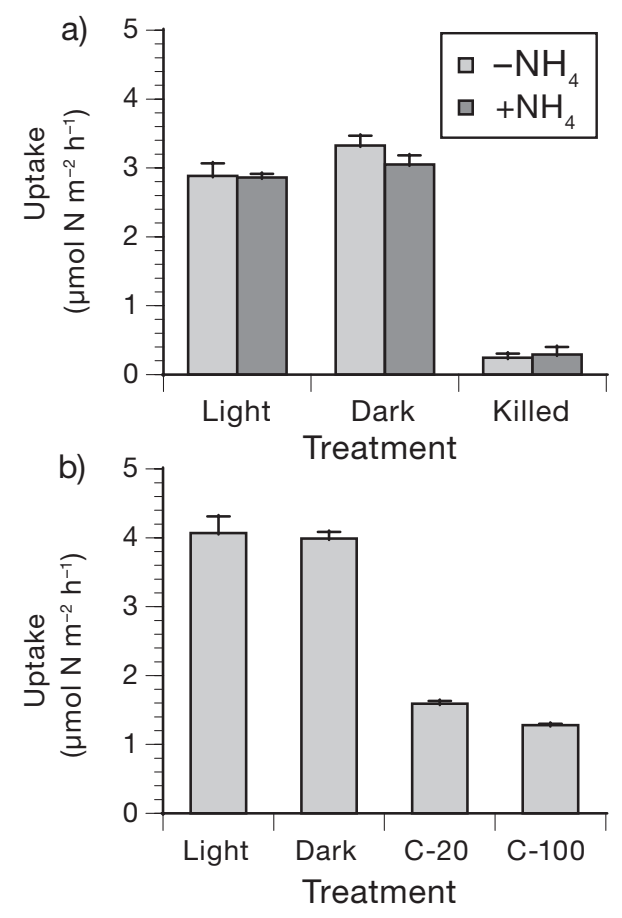

Fig. 2. DFAA uptake by isolated microphytobenthos communities (+SE), Expts 5 and 6 (Table 1). (a) Uptake of DFAA in the light and in the dark $\left(-\mathrm{NH}_{4}=\right.$ only ${ }^{3} \mathrm{H}-\mathrm{DFAA},+\mathrm{NH}_{4}=$ nonlabeled DFAA and $\mathrm{NH}_{4}$ addition); (b) light and dark uptake, and effect of chloramphenicol inhibitor (CAP) $(\mathrm{C}-20=$ $20 \mu \mathrm{mol} \mathrm{l} \mathrm{l}^{-1}$ addition, $\mathrm{C}-100=100 \mu \mathrm{mol} \mathrm{l}^{-1}$ addition) 


\section{DISCUSSION}

\section{Methods}

Our study is one of the first to attempt to measure the uptake of DFAA by mixed communities of benthic microalgae. We tried to differentiate between prokaryotic and eukaryotic ${ }^{3} \mathrm{H}$-AA uptake, and made a rough estimation of the contribution of DFAA to the $\mathrm{N}$-demand of the MPB in semi-natural communities. We also tried to check and correct for non-biological adsorption, and to avoid pre-conditioning the cells to any particular type of $\mathrm{N}$ by using ASW with no nutrient additions. Nutrient pre-conditioning may influence uptake of one $\mathrm{N}$ substrate over another, affecting uptake rates (Dzurica et al. 1989, Mulholland et al. 2004). While our experimental approach was successful in providing us with measurable uptake rates, it is not without limitations. The algal communities used in our study were manipulated to some extent, and all experiments were done in the laboratory. Our
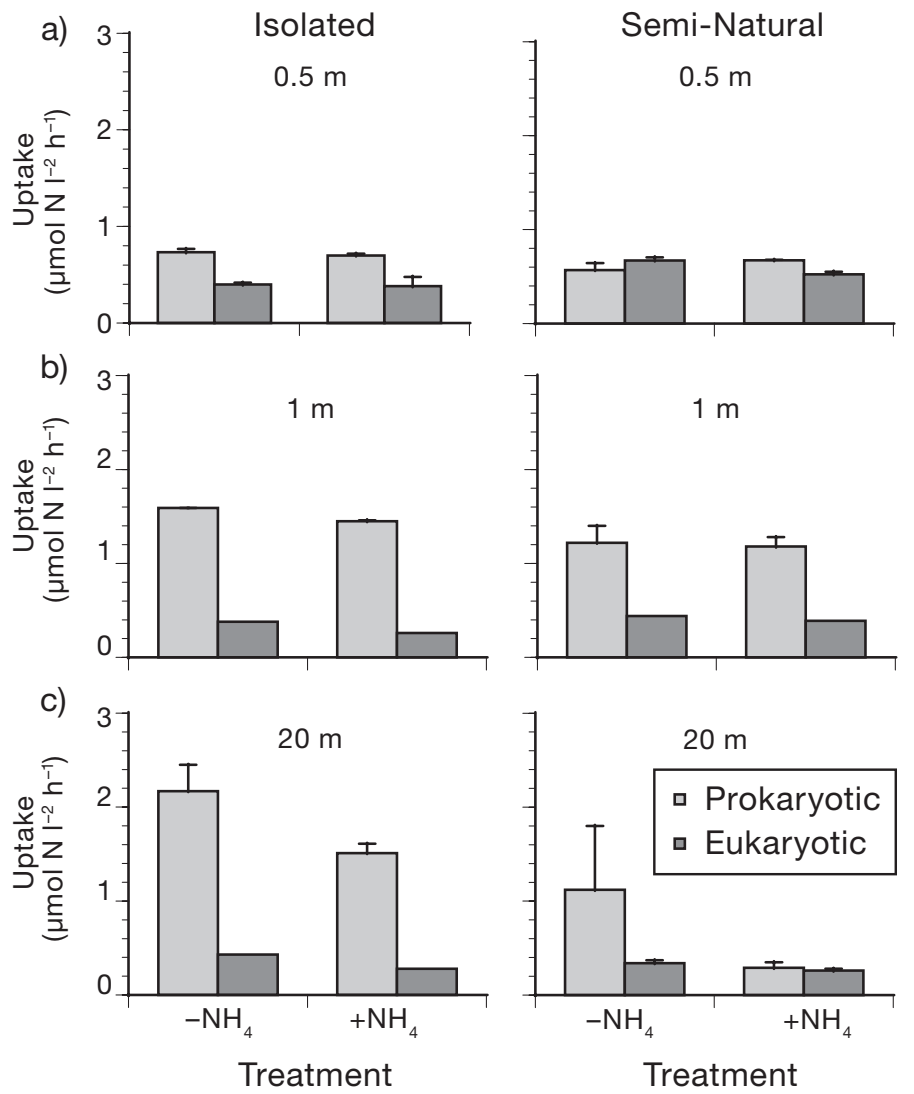

Fig. 3. DFAA uptake by isolated and semi-natural microphytobenthos communities without $\left(-\mathrm{NH}_{4}\right)$ and with addition of ammonium $\left(+\mathrm{NH}_{4}\right)$ for sediment collected from (a) $0.5 \mathrm{~m}$,

(b) $1 \mathrm{~m}$ and (c) $20 \mathrm{~m}$ depth of water, and differentiating between prokaryotic and eukaryotic uptake $(+\mathrm{SE})$ experiments were largely 'black box' experiments, where we simply measured the uptake of a mixture of ${ }^{3} \mathrm{H}-\mathrm{AA}$, without finding out the uptake mechanisms or in what form the $\mathrm{N}$ from the DFAA was used in the cells. We also did not measure the pool of available amino acids either. Despite all this, our experiments should serve as a starting point for further studies on the role of DON for natural MPB communities.

\section{DFAA uptake}

The MPB in all our experiments took up ${ }^{3} \mathrm{H}-\mathrm{AA}$ when present at low concentrations. The amount of ${ }^{3} \mathrm{H}-\mathrm{AA}$ added ( 0.13 to $\left.0.5 \mu \mathrm{mol} \mathrm{l}^{-1}\right)$ falls within the lower range of naturally occurring DFAA concentrations in pore water, which usually varies from 0.3 to $30 \mu \mathrm{M}$ in the sediment (Admiraal et al. 1987, Antia et al. 1991, Guldberg et al. 2002). However, the notion of low DFAA concentrations can be misleading given that there might be a tight coupling between production and uptake (i.e. a rapid turnover rate). Admiraal et al. (1984) concluded that isolated benthic diatom populations are able to take up DFAA even when concentrations are as low as 0.1 to $1 \mu \mathrm{mol} \mathrm{l}^{-1}$. The results obtained in our study fall within this range. Despite the fact that we were able to measure uptake in all experiments, we do not know in what form the $\mathrm{N}$ entered the cell. Palenik \& Morel (1990) first described a mechanism common to some marine phytoplankton species, where cell surface enzymes oxidize DFAA into $\mathrm{NH}_{4}$ before entering the cell. Recent studies have confirmed the importance of this extracellular oxidation pathway (Mulholland et al. 2002, 2003).

Since no previous uptake data for mixed MPB communities are available, we will instead compare our results with those reported for plankton communities. Although potential differences in uptake efficiency may exist, such comparison allows us to discuss our findings on a community level. Mulholland et al. (2003) found that natural plankton communities along an estuarine nutrient gradient derived up to $11 \%$ of the total $\mathrm{N}$ uptake in the form of DFAA. According to our estimations, the SNC from $1 \mathrm{~m}$ depth in Expt 8 could have gained roughly 6 to $12 \%$ of their hypothetical $\mathrm{N}$ demand from DFAA, which agrees well with the data reported by Mulholland et al. (2003). In a subsequent study, Mulholland et al. (2004) found that DFAA also played an important role in the $\mathrm{C}$ and $\mathrm{N}$ nutrition of the brown tide pelagophyte Aureococcus anophagefferens, where DFAA was a predominant nutrient source (ca. 18\%). Deepdwelling, shade-adapted communities (20 m depth) in our study could have gained, according to our estimations, as much as 55 to $100 \%$ of their N-demand from 
DFAA. This finding supports the idea that DON may become more important as both a $\mathrm{N}$ and $\mathrm{C}$ source as light decreases with depth (Sundbäck et al. 2004). Veuger et al. (2004) found that DFAA could contribute up to $80 \%$ of the total microbial $\mathrm{N}$ uptake, implying that DON may be an important $\mathrm{N}$ substrate for microbial communities. Middelburg \& Nieuwenhuize (2000) found similar results near the mouth of the Thames estuary.

The proportion of ${ }^{3} \mathrm{H}$-AA taken up by the eukaryotic (assumed microalgal) fraction was occasionally as high as, or even higher $(55 \%)$ than the proportion taken up by prokaryotes (bacteria) (Table 3). While CAP is primarily used as a bacteriostatic inhibitor (Shaw 1992, Steppe \& Paerl 2005), a few studies have used it to inhibit macro- and microalgae (Hader et al. 2002, Segovia \& Berges 2005). As such, the eukaryotic rates reported in our study might be underestimates, espe-
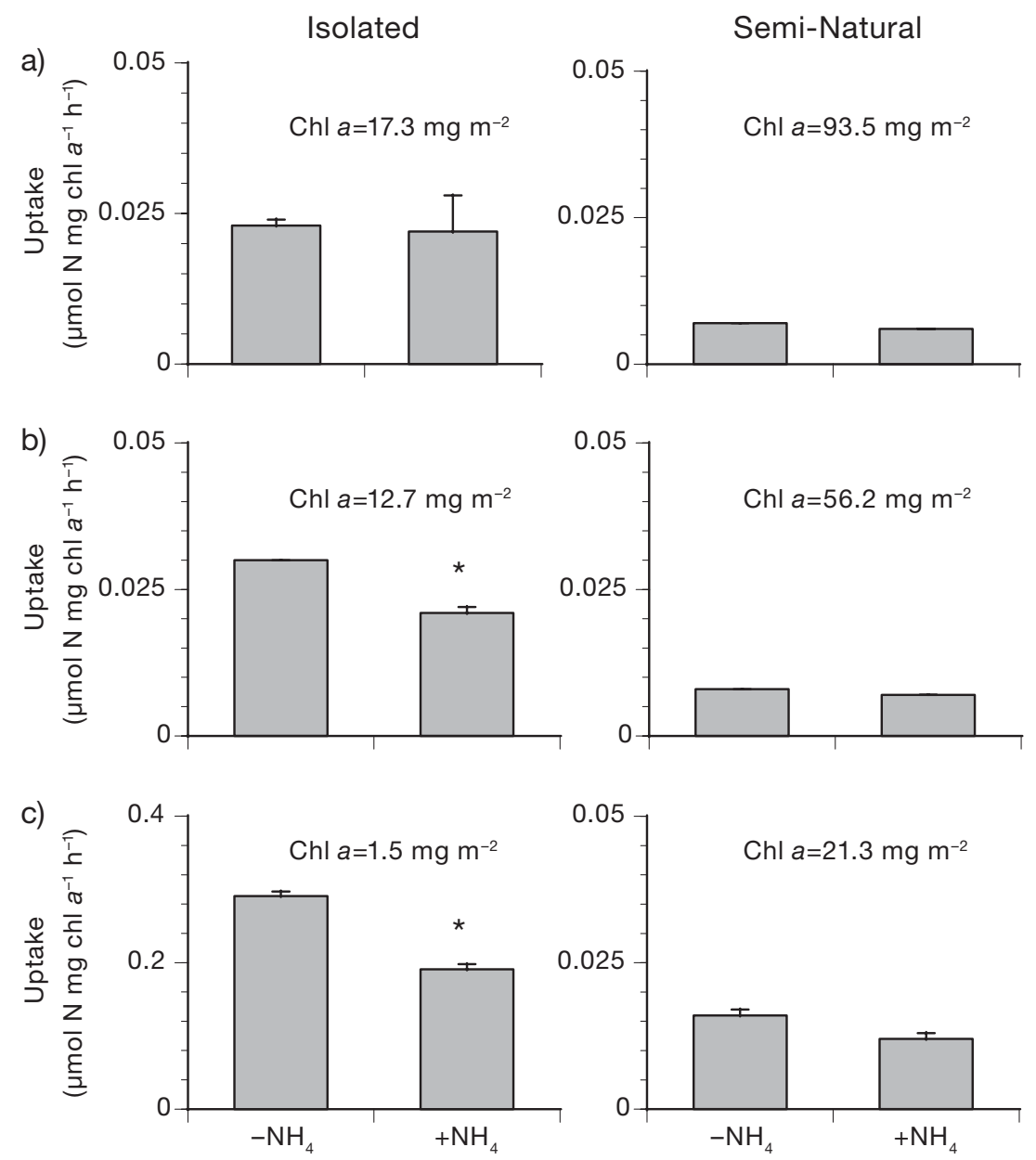

Fig. 4. DFAA uptake normalized to chlorophyll a by isolated and semi-natural microphytobenthos communities $(+\mathrm{SE})$, without $\left(-\mathrm{NH}_{4}\right)$ and with addition of ammonium $\left(+\mathrm{NH}_{4}\right)$, for sediment collected from (a) $0.5 \mathrm{~m}$, (b) $1 \mathrm{~m}$ and (c) $20 \mathrm{~m}$ depth of water. Note the difference in scales. ${ }^{*}$ Statistically significant $(p<0.05)$ difference between treatments cially if cyanobacteria are present (cf. Rondell et al. 2000). The observed high proportion of eukaryotic ${ }^{3} \mathrm{H}-\mathrm{AA}$ uptake is intriguing, since bacteria are generally considered to be the major transformers of organic matter, dominating DFAA uptake in the sediment (Blackburn \& Blackburn 1993, Herbert 1999), where they rapidly degrade amino acids (Jørgensen et al. 1981, Therkildsen et al. 1996, Lomstein et al. 1998). However, microalgae are known to effectively compete for these organic resources (Flynn \& Butler 1986), and DON uptake can be assumed to be particularly mportant when inorganic nitrogen concentrations are ow (Lomstein et al. 1998). In fact, the importance of as a $\mathrm{N}$ source for plants, on a wider global scale, sized by van Breemen (2002).

\section{Light effects}

No effect from light on ${ }^{3} \mathrm{H}$-AA uptake by MPB could be found during the incubations. Studies have suggested that light can affect the uptake of DFAA by microalgal communities (Admiraal \& Peletier 1979, Admiraal et al. 1984, Flynn \& Butler 1986). However, light effects reported in the literature vary. For example, the incorporation rate of DFAA into proteins has been found to be much higher in the light than in the dark (Flynn \& Butler 1986). In contrast, maximum rates of DFAA uptake have been suggested to occur in dark waters depleted of DIN (Flynn \& Butler 1986). Facultatively heterotrophic diatoms are capable of growth under low light conditions using DON as a nutrient and carbon source (Rivkin \& Putt 1987); moreover, DON does not necessarily enhance their growth rate when they are subjected to high irradiance (Admiraal \& Peletier 1979). One possible explanation for the lack of light effect in our study could be the incubation time, where the change in light conditions lasted only for a few hours. Shifts in DON uptake and growth of MPB using DON as a nutrient source can take days to develop (Rondell et al. 2000). When IC and SNC are grown under different light conditions for a period of 3 to $4 \mathrm{wk}$, DFAA stimulates the biomass and production of the MPB to a greater degree under high irradi- 
ance (Linares in press). Thus, it seems that short-term changes in the light climate do not affect the DFAA uptake mechanism.

Differences in DFAA uptake efficiency between communities adapted to light conditions at different depths suggested long-term effects of light. Shade-adapted eukaryotic cells in the IC were more efficient in taking up ${ }^{3} \mathrm{H}$-AA (avg. $0.13 \mu \mathrm{mol} \mathrm{mg} \mathrm{chl} \mathrm{a}^{-1} \mathrm{~h}^{-1}$ ) than lightadapted communities (avg. $0.02 \mu \mathrm{mol} \mathrm{N} \mathrm{mg} \mathrm{chl} a^{-1} \mathrm{~h}^{-1}$ ). The fact that these observations were made in the IC in particular could be because, at least initially, the IC were probably more nutrient limited than the SNC. Darkness and $\mathrm{N}$-deprivation has been found to favor the development of DFAA-uptake systems (Antia et al. 1991). Our results agree with findings that darkness favors, and $\mathrm{N}$-deprivation further accelerates, the development of DFAA-uptake systems (Flynn \& Syrett 1985, Flynn \& Butler 1986). A recent study along a depth gradient in the same study area where our light and shade-adapted
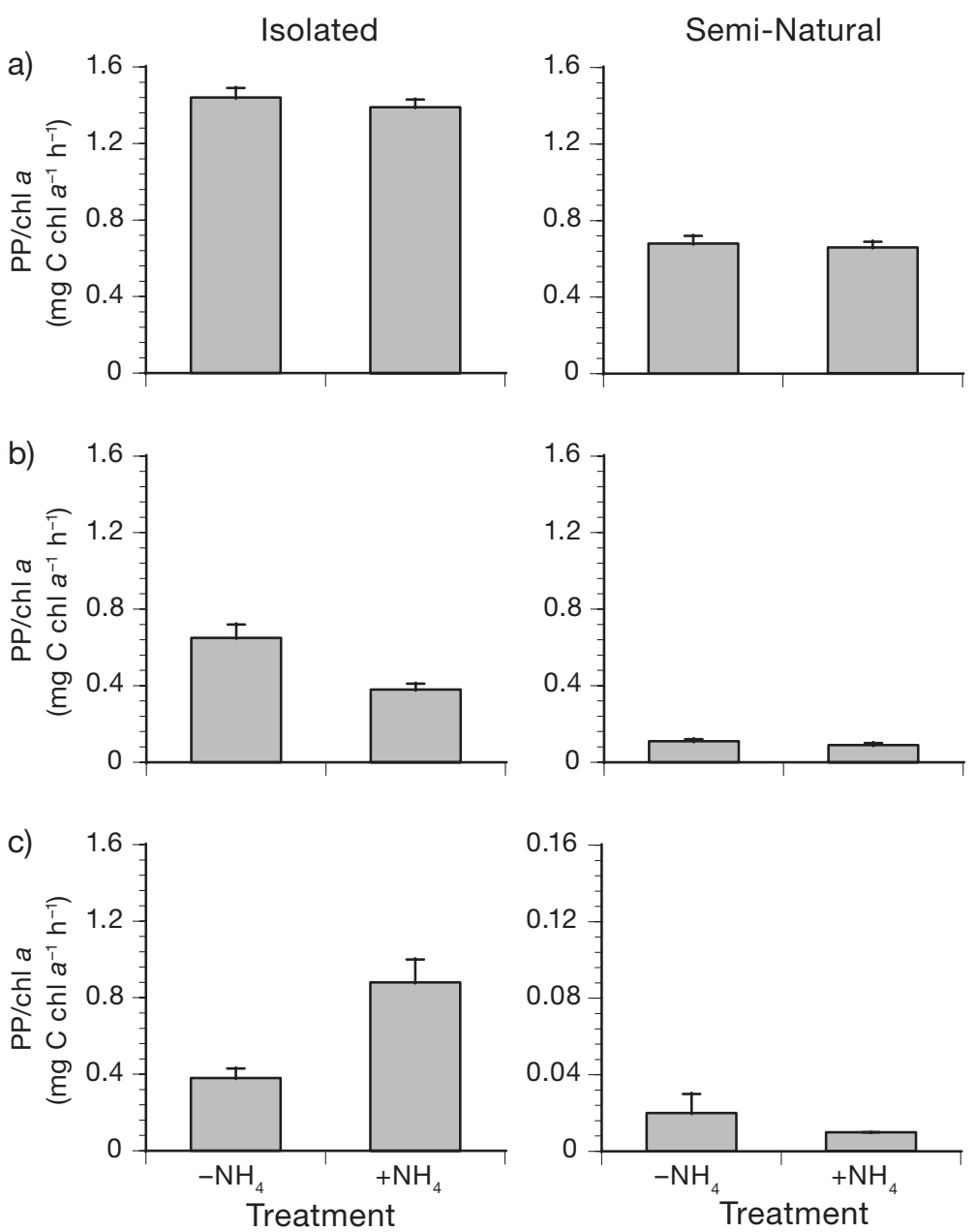

Fig. 5. Chlorophyll a normalized productivity (PP/chl a) by isolated and seminatural MPB communities $(+\mathrm{SE})$, without $\left(-\mathrm{NH}_{4}\right)$ and with addition of ammonium $\left(+\mathrm{NH}_{4}\right)$, for sediment collected from: (a) $0.5 \mathrm{~m}$, (b) $1 \mathrm{~m}$ and (c) $20 \mathrm{~m}$ depth of water. Note differences in scale sediment was collected from, found that MPB were still active at depths $>5 \mathrm{~m}$ (Sundbäck et al. 2004). Thus, it seems that these communities are well adapted to survive at these depths, which may be attributed to their effective use of organic compounds such as DFAA. Benthic microalgae are very efficient at adapting their metabolism to limiting light conditions (Admiraal \& Peletier 1979, Glud et al. 2002). Our findings also agree with those reported by Rivkin \& Putt (1987), who found that DFAA were important for periphyton growth in Antarctica under light-limiting conditions. Thus, it may be that in shallow-water sediments DFAA is mainly a $\mathrm{N}$-source when DIN is in short supply, but deeper down (or under the shade of green-algal mats for example, cf. Sundbäck et al. 1996), where light limits photosynthesis, the microalgae use DFAA both as a $\mathrm{N}$ and $\mathrm{C}$ source.

Another possible explanation for the difference in uptake between light- and shade-adapted MPB communities could be that of species composition. Our sediment communities were composed mainly of pennate diatoms (i.e. Navicula spp., Nitzchia spp.). However, Wulff et al. (2005), who studied the depth distribution of benthic diatoms along the same depth gradient, found a difference in species composition between shallow and deep sediment communities. Sundbäck et al. (2004), also working on the same depth gradient, found that deeper sediments $(>10 \mathrm{~m})$ consisted mainly of large-sized diatoms (Pleurosigma cf. clevei, Polytrichum formosum), while epipelic-epipsammic taxa (i.e. Navicula spp.) were dominant in the shallow sediments. Such a difference in species composition might also help explain the difference found between the shallow and deep sediments.

\section{Effect of $\mathrm{NH}_{4}$}

The addition of $\mathrm{NH}_{4}$ during the incubation had no effect on DFAA uptake, except in Expt 8, where eukaryotic DFAA uptake decreased, although only in the IC. Few studies exist in which the uptake of both organic and inorganic $\mathrm{N}$ sources by benthic microalgae have been studied simultaneously. Admiraal et al. (1987) studied uptake (by measuring concentrations in the media) of several amino acids, as well as DIN by 2 benthic diatom species isolated from tidal 
flats. They found that $\mathrm{NH}_{4}$ did not suppress the uptake of DFAA, whereas uptake of $\mathrm{NO}_{3}$ was suppressed. They also found that amino acids were used in parallel with ammonium, even though the concentration of DFAA $(1 \mu \mathrm{M})$ was an order of magnitude lower than that of $\mathrm{NH}_{4}$. Our experiments, using mixed MPB communities and a low concentration of DFAA $(0.5 \mu \mathrm{M})$, partly support these findings.

However, we also found that the presence of $\mathrm{NH}_{4}$ decreased ${ }^{3} \mathrm{H}-\mathrm{AA}$ uptake (Expt 8). This effect was clearest in the IC when viewed as ${ }^{3} \mathrm{H}-\mathrm{AA}^{\text {chl a }}$ uptake. One drawback of our study is that we did not measure uptake of DIN (cf. Mulholland et al. 2002) and we can only speculate about the reason for the suppression of DFAA uptake. The IC represented a more N-starved community than the SNC, where an indigenous sediment pool of both DIN and DON was available. It could be that the $\mathrm{N}$-starved algae in the IC preferred to take up $\mathrm{NH}_{4}$ when made available in a concentration 1 order of magnitude higher $(7.5 \mu \mathrm{M})$ than DFAA $(0.5 \mu \mathrm{M})$. We assume that no $\mathrm{N}$ source was available in the chemically clean sand. Both ${ }^{14} \mathrm{C}$ and ${ }^{3} \mathrm{H}$-AA uptake per unit chl a were significantly higher in the IC than in the SNC, suggesting that the algal cells in the IC were more active than those in the SNC. Admiraal et al. (1984) observed a variation between species regarding the effect of DIN on the DFAA uptake rate. Thus, as pointed out by Admiraal et al. (1984), incorporation of DFAA by natural microalgal communities is an extremely variable process, dependent on species composition and nutritional state.

The generally accepted idea that $\mathrm{NH}_{4}$ is the preferred N-source of microalgae (Antia et al. 1991, Herbert 1999) comes mainly from studies on phytoplankton species. Studies using diatoms from the sediment suggest that benthic microalgae might regulate the uptake of inorganic and organic sources in a different way than phytoplankton. The varying availability of DIN and DON may in fact determine the dominant metabolism (e.g. autotrophy vs. heterotrophy) of the community (Mulholland et al. 2004), and in some cases they may actually prefer DFAA to $\mathrm{NH}_{4}$ and $\mathrm{NO}_{3}$ (Admiraal et al. 1987). This might explain why in a previous study the addition of DFAA stimulated the growth and production of IC and SNC as much as, or even more, than the addition of $\mathrm{NO}_{3}$ (Linares in press).

\section{Estimated N-demand}

DFAA concentration in the sediment pore water was not measured. However, we estimated this concentration by assuming that 10 to $20 \%$ of DON is in the form of DFAA (Guldberg et al. 2002). One of our initial aims was to test whether shade-adapted MPB communities were more efficient at taking up DFAA than lightadapted communities. This assumption is based on the idea that facultative heterotrophy (including uptake of dissolved organic carbon [DOC] and DON) of microalgae becomes more important as light becomes scarce (Admiraal \& Peletier 1979). The estimated contribution from DFAA to the microalgal $\mathrm{N}$-demand was much higher in the $20 \mathrm{~m}$ sediment (55 to $100 \%$ ) than in the $1 \mathrm{~m}$ sediment (6 to $12 \%$ ). A recent study conducted along a depth gradient in the Gullmar fjord found occasional DON uptake by the sediment, as well as light effects on DON flux, particularly at depths greater than $5 \mathrm{~m}$. These findings suggest that DON uptake by microalgae may be important at sublittoral depths (Sundbäck et al. 2004). The relatively high ${ }^{3} \mathrm{H}$-AA uptake rates measured in the $20 \mathrm{~m}$ sediment, and the high percentage of DFAA estimated to contribute to the total N-demand, support these findings. Moreover, it is possible to theorize from the estimated percentage that the microalgae use DFAA as both a $\mathrm{N}$ and C source (cf. Mulholland et al. 2002).

\section{CONCLUSIONS}

Our results showed that sediments with mixed MPB communities can take up DFAA when occurring in naturally low concentrations $(<1 \mu \mathrm{M})$. Short-term changes in light conditions do not appear to affect the uptake rate of DFAA and rates are only marginally lowered by ammonium availability. Although prokaryotic uptake of DFAA often dominates, eukaryotic (algal) uptake can occasionally be as high as the prokaryotic uptake. Tentative estimations suggest that DFAA can provide MPB communities with a considerable portion of their total $\mathrm{N}$-demand ( 10 to $100 \%)$. An efficient uptake of DFAA may be an important adaptation mechanism particularly under light-limited conditions, where DFAA can be assumed to also provide an alternative $C$ source when photosynthesis is strongly light-limited. It is suggested that labile fractions of DON, such as DFAA, may be an important alternative $\mathrm{N}$ source for natural MPB communities, in particular when ambient DIN concentrations are low.

Acknowledgements. Funding for this study was received from the MISTRA Foundation, the Swedish Research Council for Environment, Agricultural Sciences and Special Planning (FORMAS), the Royal Society of Arts and Sciences in Göteborg, the Göteborg University Marine Research Centre, the Foundation in the Memory of Birgit and Birger Wåhlström, and the Captain Stenholm Fund. We thank Dr. S. Hulth and P. Engström for gracious help during the sampling, as well as the crew of the RV 'Oscar von Sydow'. We also thank Dr. S.-A. Wängberg for advice concerning the methodology. Two anonymous reviewers are acknowledged for their valuable comments. 


\section{LITERATURE CITED}

Admiraal W, Peletier H (1979) Influence of organic compounds and light limitation on the growth rate of estuarine benthic diatoms. Br Phycol J 14:197-206

Admiraal W, Laane RWPM, Peletier H (1984) Participation of diatoms in the amino acid cycle of coastal waters; uptake and excretion in cultures. Mar Ecol Prog Ser 15:303-306

Admiraal W, Riaux-Gobin C, Laane RWPM (1987) Interactions of ammonium, nitrate, and $\mathrm{D}$ - and L-amino acids in the nitrogen assimilation of two species of estuarine benthic diatoms. Mar Ecol Prog Ser 40:267-273

Aertebjerg Nielsen G, Bresta AM (1984) Guidelines for the measurements of phytoplankton primary production. Baltic Mar Biol (BMB) Publ No 1, 2nd edn. Marine Pollution Laboratory, Charlottenlund

Anderson IC, McGlathery KJ, Tyler AC (2003) Microbial mediation of 'reactive' nitrogen transformations in a temperate lagoon. Mar Ecol Prog Ser 246:73-84

Antia NJ, Harrison PJ, Oliveira L (1991) The role of dissolved organic nitrogen in phytoplankton nutrition, cell biology and ecology. Phycologia 30:1-89

Aufdekampe AK, Hedges JI, Richey JE, Krusche AV, Llerena CA (2001) Sorptive fractionation of dissolved organic nitrogen and amino acids onto fine sediments within the Amazon Basin. Limnol Oceanogr 46:1921-1935

Blackburn TH, Blackburn ND (1993) Rates of microbial processes in sediments. Phil Trans R Soc Lond 344:49-58

Bronk DA, Lomas MW, Glibert PM, Schukert KJ, Sandersson MP (2000) Total dissolved nitrogen analysis: comparisons between the persulfate, UV and high temperature oxidation methods. Mar Chem 69:163-178

Carman KR, Guckert JB (1994) Radiotracer determination of ingestion and assimilation of periphytic algae, bacteria, and adsorbed amino acids by snails. J North Am Benthol Soc 13:80-88

Christensen D, Blackburn TH (1980) Turnover of tracer $\left({ }^{14} \mathrm{C}\right.$, ${ }^{3} \mathrm{H}$ labeled) alanine in inshore marine sediments. Mar Biol 58:97-103

Dzurica S, Lee C, Cosper EM, Carpenter EJ (1989) Role of environmental variables, specifically organic compounds and micronutrients, in the growth of the chrysophyte Aureococcus anophagefferens. In: Cosper EM, Bricelj VM, Carpenter EJ (eds) Novel phytoplankton blooms: causes and impacts of recurrent brown tides and other unusual blooms. Springer-Verlag, Berlin, p 229-252

Flothmann S, Werner I (1992) Experimental eutrophication on an intertidal sandflat: effects on microphytobenthos, meioand macrofauna. In: Colombo G, Ferrari I, Ceccherelli V, Rossi R (eds) Marine eutrophication and population dynamics. Olsen \& Olsen, Fredensborg, p 93-100

Flynn KJ, Butler I (1986) Nitrogen sources for the growth of marine microalgae: role of dissolved free amino acids. Mar Ecol Prog Ser 34:281-304

Flynn KJ, Syrett PJ (1985) Development of the ability to take up L-lysine by the diatom Phaeodactylum tricornutum. Mar Biol 89:317-325

Glud RN, Kühl M, Wenzhöfer F, Rysgaard S (2002) Benthic diatoms of a high Arctic fjord (Young Sound, NE Greenland): importance of ecosystem primary production. Mar Ecol Prog Ser 238:15-29

Guldberg LB, Finster K, Jørgensen NOG, Middelboe M, Lomstein BA (2002) Utilization of marine sedimentary dissolved organic nitrogen by native anaerobic bacteria. Limnol Oceanogr 47:1712-1722

Hader DP, Lebert M, Sinha RP, Barbieri ES, Helbling EW (2002) Role of protective and repair mechanisms in the inhibition of photosynthesis in marine macroalgae. Photochem Photobiol Sci 1(10):809-814

Henriksen K, Hansen J, Blackburn TH (1980) The influence of benthic infauna on exchange rates of inorganic nitrogen between sediment and water. Ophelia (Suppl) 1:249-256

Herbert RA (1999) Nitrogen cycling in coastal marine systems. FEMS Microbiol Rev 23:563-590

Jørgensen NOG, Blackburn TH, Henriksen K, Bay D (1981) The importance of Posidonia oceanica and Cymodocea nodosa as contributors of free amino acids in water and sediment of seagrass beds. Mar Ecol 2:97-112

Kristensen E (1993) Seasonal variations in benthic community metabolism and nitrogen dynamics in a shallow, organicpoor Danish Lagoon. Estuar Coast Shelf Sci 36:565-586

Linares F (in press) Effect of dissolved free amino acids (DFAA) on the biomass and production of microphytobenthic communities. J Environ Mar Biol Ecol

Lomstein BA, Jensen AGU, Hansen JW, Andreasen JB, Hansen LS, Berntsen J, Kunzendorf H (1998) Budgets of sediment nitrogen and carbon cycling in the shallow water of Knebel Vig, Denmark. Aquat Microb Ecol 14:69-80

Lorenzen CJ (1967) Determination of chlorophyll and pheopigments: spectrophotometric equations. Limnol Oceanogr 12:343-346

McGlathery K, Sundbäck K, Anderson IC (2004) The importance of primary producers for benthic nitrogen and phosphorus cycling. In: Nielsen SL, Banta GT, Pedersen MF (eds) Estuarine nutrient cycling: the influence of primary producers. Springer, Berlin, p 231-261

Middelburg JJ, Nieuwenhuize J (2000) Nitrogen uptake by heterotrophic bacteria and phytoplankton in the nitraterich Thames estuary. Mar Ecol Prog Ser 203:13-21

Mulholland MR, Gobler CJ, Lee C (2002) Peptide hydrolysis, amino acid oxidation, and nitrogen uptake in communities seasonally dominated by Aureococcus anophagefferens. Limnol Oceanogr 47:1094-1108

Mulholland MR, Lee C, Gilbert PM (2003) Extracellular enzyme activity and uptake of carbon and nitrogen along an estuarine salinity and nutrient gradient. Mar Ecol Prog Ser 258:3-17

Mulholland MR, Boneillo G, Minor EC (2004) A comparison of $\mathrm{N}$ and $\mathrm{C}$ uptake during brown tide (Aureococcus anophagefferens) blooms from two coastal bays on the east coast of the USA. Harmful Algae 3:361-376

Nilsson C, Sundbäck K (1991) Growth and nutrient uptake studied in sand-agar microphytobenthic communities. J Exp Mar Biol Ecol 153:207-226

Nilsson C, Sundbäck K (1996) Amino acid uptake by natural benthic microalgal assemblages studied by microautoradiography. Hydrobiologia 332:119-129

Nilsson P, Jönsson B, Lindström Swanberg I, Sundbäck K (1991) Response of a marine shallow-water sediment system to an increased load of inorganic nutrients. Mar Ecol Prog Ser 71:275-290

Palenik B, Morel FMM (1990) Amino acid utilization by marine phytoplankton: a novel mechanism. Limnol Oceanogr 35: 260-269

Risgaard-Petersen N (2003) Coupled nitrification-denitrification in autotrophic and heterotrophic estuarine sediments: on the influence of benthic microalgae. Limnol Oceanogr 48:93-105

Rivkin RB, Putt M (1987) Heterotrophy and photoheterotrophy by Antarctic microalgae: light-dependent incorporation of amino acids and glucose. J Phycol 23: $442-452$

Rondell JB, Finster KW, Lomstein BA (2000) Urea and DON uptake by a Lyngbya gracilis dominated microbial mat: 
a controlled laboratory experiment. Aquat Microb Ecol 21: 169-175

Schuster S, Arrieta JM, Herndl GJ (1998) Adsorption of dissolved free amino acids on colloidal DOM enhances colloidal DOM utilization but reduces amino acid uptake by orders of magnitude in marine bacterioplankton. Mar Ecol Prog Ser 166:99-108

Segovia M, Berges JA (2005) Effect of inhibitors of protein synthesis and DNA replication on the introduction of proteolytic activities, caspase-like activities and cell death in the unicellular chlorophyte Dunaliella tertiolecta. Eur J Phycol 40(1):21-30

Shaw WV (1992) Chemical anatomy of antibiotic-resistance chloramphenicol acetyltransferase. Sci Prog 76(301-02): $565-580$

Steppe TF, Paerl HW (2005) Nitrogenase activity and nifH expression in a marine intertidal microbial mat. Microb Ecol 49(2):315-324

Sundbäck K, Jönsson B, Nilsson P, Lindström I (1990) Impact of accumulating drifting macroalgae on a shallow-water sediment system: an experimental study. Mar Ecol Prog Ser 58:261-274

Sundbäck K, Carlson L, Nilsson C, Jönsson B, Wulff A, Odmark S (1996) Response of benthic microbial mats to drifting green algal mats. Aquat Microb Ecol 10:195-208

Sundbäck K, Miles A, Göransson E (2000) Nitrogen fluxes, denitrification and the role of microphytobenthos in microtidal shallow-water sediments: an annual study. Mar Ecol Prog Ser 200:59-76

Sundbäck K, Linares F, Larson F, Wulff A, Engelsen A (2004) Benthic nitrogen fluxes along a depth gradient in a microtidal fjord: the role of denitrification and microphytobenthos. Limnol Oceanogr 49:1095-1107

Editorial responsibility: Bess B. Ward, Princeton, New Jersey, USA
Therkildsen MS, King GM, Lomstein BA (1996) Urea production and turnover following the addition of AMP, CMP, RNA and a protein mixture to a marine sediment. Aquat Microb Ecol 10:173-179

Tyler AC, McGlathery KJ, Anderson IC (2001) Macroalgae mediation of dissolved organic nitrogen fluxes in a temperate coastal lagoon. Estuar Coast Shelf Sci 53: 155-168

Tyler AC, McGlathery K, Anderson IC (2003) Benthic algae control sediment-water column fluxes and inorganic nitrogen compounds in a temperate lagoon. Limnol Oceanogr 48:2125-2137

Underwood GJC, Kromkamp J (1999) Primary production by phytoplankton and microphytobenthos in estuaries. Adv Ecol Res 29:93-153

Valderrama JC (1981) The simultaneous analysis of total nitrogen and total phosporus in natural water. Mar Chem 10:109-122

van Breemen N (2002) Natural organic tendency. Nature 415:381-382

Veuger B, Middelburg JJ, Boschker HTS, Nieuwenhuize J, Rijswijk P, Rochelle-Newall EJ, Navarro N (2004) Microbial uptake of dissolved organic and inorganic nitrogen in Randers Fjord. Estuar Coast Shelf Sci 61:507-515

Voltolina D (1991) A comparison of methods for the dispersion of cultures of benthic diatoms. Cryptogam Algol 12(3): 183-187

Wulff A, Vilbaste S, Truu J (2005) Depth distribution of photosynthetic pigments and diatoms in the sediments of a microtidal fjord. Hydrobiologia 534:117-130

Zehr J, Ward B (2002) Nitrogen cycling in the ocean: new perspectives on processes and paradigms. Appl Environ Microbiol 68:1015-1024

Submitted: July 6, 2005; Accepted: December 8, 2005 Proofs received from author(s): February 17, 2006 